\title{
UITBRANDING IN DIE BEDIENING
}

\section{A J SMUTS}

\begin{abstract}
Ministry burnout

Burnout is a hazard to which professional care-givers in the various helping professions are exposed. In this article burnout is described as a multidimensional construct, characterised by a state of emotional overload and subsequent exhaustion, resulting in a state of emotional detachment and depersonalisation. This must be differentiated from related conditions, such as tedium, stress and depression. Burnout as an occupational hazard in the ministry is then discussed. In his daily work the minister is confronted with a situation in which a variety of factors are present which may lead to the state of burnout. The risk increases when a combination of factors leading up to it are present. Interpersonal relations, job setting and personal characteristics all play a part in the development of this problem. Finally, various ways in which such a state of burnout may be prevented are discussed. The minister must arm himself with the necessary knowledge (especially self-knowledge). A balanced life-style and constant renewal of his physical, mental, emotional and spiritual life are prime requisites. For the minister this means, inter alià, that he should keep up his study of theology and devote attention to his personal devotions.
\end{abstract}

Die afgelope paar jaar het 'n nuwe woord so stilweg sy verskyning in ons woordeskat gemaak: Uitbranding. Hierdie term, wat verwys na 'n reaksie wat veral by beoefenaars van sekere mensgerigte beroepe waargeneem word, is besonder beskrywend en roep by die hoorder onmiddellik allerlei assosiasies op.

By een persoon mag dit die beeld oproep van 'n vuur wat uitgebrand het, totdat daar nie meer vlamme of selfs gloeiende kole is nie, maar net koue wit as. lemand anders dink moontlik weer aan ' $n$ huis wat afgebrand het: waar vroeër ' $n$ nuttige en sierlike woning gestaan het, is nou net ' $n$ swartgebrande murasie wat onbewoonbaar en vir niemand meer tot enige nut is nie. lemand anders gebruik weer die beeld van ' $n$ uitgebrande motorwrak wat langs die pad lế1). In sy boek "Ministry Burnout" verwys John A Sanford 2) na nog 'n verdere betekenis wat hierdie woord in die Engelse taal het. Volgens Webster se woordeboek verwys dit na ' $n$ bosbrand wat so erg is dat dit nie net die plantegroei verteer nie, maar selfs ook die humus onder op die grond. Alles is weggebrand, sodat net die kaal, onvrugbare bodem oorbly, wat geen nuwe lewe kan voed nie.

Al hierdie assosiasies wys op een van die grootste probleme rond- 
om die begrip "uitbranding" wanneer dit in hierdie besondere betekenis op mense toegepas word. Juis omdat dit so ' $n$ beskrywende woord is, is die hoorder geneig om onmiddellik aan te neem dat hy presies weet wat dit beteken en dan kleur hy dit met sy eie assosiasies in. Hy meen dan maklik dat om aan uitbranding te ly, min of meer dieselfde sou beteken as om uitgeput en moeg te voel.

Daarmee het hierdie term dieselfde weg gevolg as ander sielkundige terme soos "kompleks" (wat in die navorsing van Jung 'n spesifieke en eksakte betekenis het) of "neuroties" (wat weer by Freud 'n spesifieke betekenisinhoud gehad het), maar wat mettertyd 'n betekenisvervanging en -vervlakking ondergaan het toe dit deel van die spreektaal geword het.

In werklikheid is die sindroom van uitbranding ' $n$ baie spesifieke toestand wat gedurende die afgelope jare deur verskillende navorsers noukeurig nagegaan en omskryf is: ' $n$ Uitgebreide literatuur het gedurende die afgelope sowat 12 jaar rondom hierdie verskynsel ontstaan, sodat dit vandag steeds moeiliker word om dit werklik te beheers. Dit dui ongetwyfeld daarop dat die verskynsel van uitbranding 'n saak van belang is. $\mathrm{F} \mathrm{J} \mathrm{Odendal,}{ }^{3)}$ wat met die oog op sy MA-verhandeling in 1984 'n empiriese ondersoek gedoen het na die voorkoms van uitbranding onder predikante van die Ned Geref Kerk, vermeld dat navorsing op daardie stadium reeds gedoen was met verteenwoordigers van bykans alle hulpverlenende beroepe. So bestaan daar studies oor uitbranding by mediese dokters, verpleegkundiges, maatskaplike werkers, onderwysers, dosente, psigoterapeute, psigiaters, predikante, polisie, proefbeamptes, tronkbewaarders, prokureurs en nog vele ander.

Aanvanklik was die aandag hoofsaaklik gevestig op persone in beroepe binne die veld van geestesgesondheid, en het die bediening as plek waar uitbranding 'n beroepsrisiko vorm, nie veel aandag geniet nie. In 1982, etlike jare nadat hierdie term vir die eerste maal die aandag begin trek het, kon Taylor" nog die stelling maak: "No empirical studies currently exist involving ministers and burnout." Hierdie stand van sake het egter intussen verander, sodat daar tans 'n groot aantal studies, artikels in wetenskaplike en populêre tydskrifte sowel as hoofstukke in boeke oor die verskynsel van uitbranding in die bediening gevind kan word.

\section{OMSKRYWING VAN DIE SINDROOM}

Onder die term "sindroom" word verstaan 'n groep simptome wat aanduidend is van ' $n$ kliniese entiteit. . $^{5}$ Die siektebeeld of sindroom van die toestand van uitbranding is met verloop van tyd deur verskillende per- 
sone op verskillende maniere omskryf. Een van die bondigste en beste omskrywings daarvan vind ons in ' $n$ artikel van Perlman en Hartman wat in 1982 in die tydskrif Human Relations onder die opskrif "Burnout: Summary and future research" verskyn het. ${ }^{6)}$ In hierdie artikel gee hulle 'n oorsig oor 'n groot aantal publikasies oor dié onderwerp wat tussen die jare 1974 en 1981 verskyn het en op grond daarvan bied hulle die volgende definisie van die verskynsel van uitbranding: Dit is 'n respons op kroniese emosionele spanningsdruk (stres) wat uit drie komponente bestaan:

(a) Emosionele en/of fisiese uitputting,

(b) Verlaagde werksproduktiwiteit, en

(c) Oormatige depersonalisasie.

Hulle is van oordeel dat uitbranding beskou moet word as 'n multidimensionele konstruk. Dit is ' $n$ reaksie wat aangetref word by persone wat kroniese emosionele spanning ervaar omdat hulle met mense moet werk, veral wanneer daardie mense voortdurend aan die helpende persoon emosionele eise stel, maar aan die ander kant min teruggee in die vorm van waardering, ondersteuning, bemoediging, ensovoorts. Wanneer in die lig van hierdie stelling nou weer na die lys van beroepe waar uitbranding ' $n$ probleem vorm, gekyk word, is dit duidelik dat die verteenwoordigers daarvan dikwels juis onder sulke moeilike en dikwels ontmoedigende omstandighede hulle werk moet doen.

Om die toestand van uitbranding goed te verstaan, is dit egter nodig om iets meer omtrent elkeen van genoemde bydraende faktore te sê.

Een van die persone wat seker die meeste navorsing oor die verskynsel van uitbranding gedoen het en ook veel daaroor geskryf het, is Christina Maslach. Sy het ook 'n instrument ontwikkel waarmee uitbranding gemeet kan word, die sogenaamde "Maslach Burnout Inventory". In haar boek ${ }^{7}$ Burnout bespreek sy hierdie sindroom breedvoerig.

Die kern van die saak is emosionele oorlading van die betrokke persoon, met gevolglike emosionele uitputting. lemand raak emosioneel oorbetrokke by sy werk en by die'persone met wie hy moet werk, met die gevolg dat hy homself oormatig gee aan diegene wat voortdurend op sy hulp en aandag aanspraak maak. Dit is 'n loflike ideaal om onbeperk tot beskikking van ander te wees wanneer hulle jou nodig het, maar die harde werklikheid is dat elkeen van ons net oor ' $n$ beperkte hoeveelheid innerlike reserwes beskik. Wanneer die eise te veel uit die persoon haal, raak hierdie voorrade uitgeput, en dit lei dan tot 'n toestand van emosionele uitputting. 'n Onderwyser het dit soos volg beskryf: 
"A teacher can be compared to a battery. At the beginning of the school year, all the students are plugged in and drawing learning current. At the end of the school year, the battery is worn down and must be recharged. And each time the battery is recharged it is more difficult to get it to hold its charge, and eventually it must be replaced." 8 ,

As dit dan is hoe die toestand in sy geheel daar uitsien, moet ook op die samestellende dele daarvan gelet word. Die verskillende komponente wat deel van hierdie proses van uitbranding uitmaak, is van belang:

\section{Emosionele uitputting}

Dit is netjies beskryf met die term "compassion fatigue", wat laat dink aan die term "metal fatigue" wat byvoorbeeld by vliegtuie aangetref word wanneer hulle te lank blootgestel was aan die stormweer waardeur hulle moes vlieg.

Omdat die persoon emosioneel gedreineer voel, begin hy sy kontakte met diegene wat hom nodig het, verminder. Hy kan dit nie meer hanteer nie, want hy is moeg. Hy wil nie meer gepla word deur mense wat tydig en ontydig aansprake op hom maak nie. Daarom wil hy eenvoudig nie meer emosioneel betrokke raak by hulle probleme nie - hy het ' $n$ oordosis daarvan gehad.

Die emosionele uitputting lei dus daartoe dat die helpende persoon 'n soort harnas aantrek om hom minder kwesbaar te maak. Hy vorm onwillekeurig 'n soort emosionele "dop" om homself, waarin hy soos 'n slak kan terugtrek. Die groot probleem van hierdie reaksie is dat die dop ongemerk so dik kan word dat geen gevoelens meer daar kan deurkom nie, met die gevolg dat die persoon wat aanvanklik so simpatiek en invoelend was, mettertyd gevoelloos word wat betref die nood van mense wat hom nodig het.

\section{Depersonalisasie}

Die dikvellige houding wat die gevolg is van emosionele ooreising lei egter tot 'n tweede kenmerk van die sindroom van uitbranding, naamlik depersonalisasie. Dit beteken dat die persoon ver van mense af voel. Dit voel of hy nie met hulle kan kontak maak nie. Daarmee saam gaan egter ook 'n negatiewe houding teenoor ander. Diegene wat jou hulp nodig het, word so ' $n$ las dat hulle byna jou vyande word. 'n Ma wat dag na dag moet omsien na ' $n$ huis vol klein kindertjies kan as gevolg van die eise wat hulle sonder ophou aan haar stel so negatief word dat sy oormatig kwaai en humeurig is, terwyl sy in werklikheid tog lief is vir haar kinders. 


\section{Verlaagde prestasie}

Dit is natuurlik nie so dat die persoon wat op hierdie wyse verander dit nie self agterkom nie. Hy merk dat sy hele instelling verander en voel dikwels skaam daaroor. Dit voel vir hom of hy ' $n$ totale mislukking is. Dit word deur Maslach" beskryf as die "mea culpa"-reaksie: die betrokke persoon voel dat die fout by hom persoonlik geleë is en dan blameer hy homself. Hy voel heeltemal ontoereikend vir die taak wat hy moet verrig, en versink dus in ' $n$ toestand van apatie: hy onttrek hom en doen slegs die minimum. Sommige dien in hierdie stadium hulle bedanking by hulle werk in, omdat hulle nie kans sien om langer daarmee voort te gaan nie. Hierdie geesteshouding lei ook daartoe dat die persoon mag neig om enige hulp wat beskikbaar is van die hand te wys, omdat hy glo dat hy in elk geval ontoereikend is.

Wat hierbo beskryf is, is ' $n$ volwaardige toestand van uitbranding waarvan die simptome duidelik herkenbaar is. Gelukkig is nie alle gevalle van uitbranding so ver gevorderd nie en dit is moontlik om die simptome daarvan vroegtydig raak te sien en die nodige maatreëls te tref om 'n krisis te voorkom. In die literatuur is daar sprake van verskillende grade waarin hierdie toestand kan voorkom. Ons kan die volgende drie vlakke van die toestand van uitbranding onderskei:

(a) Daaglikse uitbranding: Sommige beroepe is besonder veeleisend en lei daartoe dat die beoefenaars daarvan aan die einde van die dag heeltemal uitgeput voel. Daarby kan nog die gevoel heers dat jou moeite eintlik tevergeefs was en dat diegene vir wie jy jouself afgesloof het, dit eintlik nie waardeer het nie. Fisiese simptome, soos hoofpyn, gaan dikwels hiermee gepaard. Gelukkig is hierdie gevoelens dikwels nie van lange duur nie. 'n Goeie nagrus help al baie, terwyl 'n bietjie ondersteuning, simpatie en bemoediging van die kant van jou huismense daartoe bydra om die nodige balans te herwin.

(b) Die tweede en meer gevorderde vlak van uitbranding tree in wanneer hierdie toestand meer gereeld begin voorkom, sodat dit werklik ' $n$ probleem word. As mens byvoorbeeld elke dag hoofpyn het, is dit ' $n$ teken dat daar iets is wat nie in orde is nie.

(c) Dit kan dan lei tot die derde vlak, wanneer dit 'n kroniese toestand geword het. Afgesien van die siektebeeld wat hierbo beskryf word, kan hierdie kroniese toestand van uitbranding ook gepaard gaan met ernstiger fisiese probleme, soos 'n maagseer of herhaaldelike migrainehoofpyne. Dit is ook duidelik dat dit in hierdie stadium moeiliker is om die 
toestand reg te stel. Voorkoming is veel beter as latere pogings tot genesing, wat aangewend mag word wanneer veel skade reeds aangerig is.

\section{DIFFERENSIASIE}

Die toestand van uitbranding vertoon verwantskap met ' $n$ aantal ander sake, waarvan dit egter onderskei moet word.

\section{Tedium}

In die gewone spreektaal word onder "tedium" 'n toestand van verveeldheid verstaan. Dit is verstaanbaar dat as daar niks boeiends en interessants in iemand se werksituasie is nie, dit 'n sieldodende ervaring kan word. In die vakliteratuur word die begrip "tedium" in hierdie verband egter in ' $n$ ietwat breër betekenis gebesig. Pines en Aronson ${ }^{10}$ ' het die verskil tussen tedium en uitbranding soos volg omskryf: "Tedium can be the result of any prolonged chronic pressures (mental, physical, or emotional); burnout is the result of constant or repeated emotional pressure associated with an intense involvement with people over long periods of time."

Tedium is dus in ' $n$ sekere sin 'n breër begrip as uitbranding. Dit dui op die effek van slopende druk wat oor ' $n$ lang tydperk strek en so veeleisend is dat die persoon dit nie kan uithou nie. Uitbranding, daarenteen, is ' $n$ spesifieke reaksie wat verband hou met emosionele eise in ' $n$ interpersoonlike situasie.

\section{Stres}

In 'n deeglike artikel het Archibald D Hart ${ }^{11)}$ die onderskeid tussen stres of spanningsdruk enersyds en uitbranding andersyds uitgespel. Hy wys daarop dat die oorsake van hierdie twee toestande uiteenlopend is en dat die weg tot genesing verskil wat uitbranding en stres betref. Omdat dit nie dieselfde saak is nie, kan 'n duidelike onderskeiding ook help om beter voorkomingsmaatreëls in elke geval te ontwerp.

Stres is deur die vader van die begrip, Hans Selye, omskryf as 'n nonspesifieke reaksie van die liggaam op (buitengewone) eise wat daaraan gestel word. Die liggaam reageer op hierdie eise deur. seker streshormone af te skei. As die persoon egter nie aktief optree tydens so 'n stressituasie nie (iets wat gewoonlik deur die reëls van ons samelewing verbied word) lei dit tot ' $n$ toestand waarin 'n oorproduksie van adrenalien deur die liggaam beskikbaar gestel word vir hantering van die noodsi- 
tuasie, maar nie verbruik word nie. Vir die liggaam is dit nadelig om voortdurend in so 'n gereedheidstoestand gehou te word. Stres kan omskryf word as 'n "hurry sickness"': die slagoffer daarvan word voortgedryf tot by breekpunt, wat gewoonlik onverwags in die vorm van ' $n$ hartaanval, 'n beroerte-aanval of 'n maagseer aanmeld.

Uitbranding verskil van stres daarin dat dit 'n emosionele toestand is, wat juis die rem so ' $n$ bietjie aandraai. Dit bring mee dat die persoon wat besig is om te veel van homself te gee, begin onttrek voordat hy werklik breekpunt bereik. In ' $n$ sekere $\sin$ is dit dus ' $n$ ingeboude veiligheidsmeganisme.

\section{Depressie}

Depressie is ' $n$ negatiewe gevoelsreaksie wat 'n simptoom kan wees van 'n groot aantal siektetoestande van fisiese en psigiese aard. In sommige gevalle is die depressie natuurlik self die probleem en is dit nie bloot ' $n$ begeleidende verskynsel nie. Die probleem is egter dat depressie 'n baie meer bekende saak is as uitbranding, met die gevolg dat die een dikwels vir die ander aangesien word. Depressie is meestal in die geval van uitbranding simptomaties aanwesig: die persoon wat aan uitbranding ly, voel dikwels moedeloos en terneergedruk. Hart ${ }^{12)}$ verklaar die aanwesigheid van depressiewe gevoelens by persone wat aan uitbranding ly uit twee stelle faktore:

(a) Die fisiologiese stelsels van die persoon se liggaam begin meegee onder die druk van die probleme wat hy ondervind.

(b) Uit die beskrywing wat hierbo van die ervaring van uitbranding gegee is, is dit duidelik dat die persoon wat in hierdie toestand verkeer, homself en sy situasie op 'n baie negatiewe wyse waarneem. Hy vind min vreugde en bevrediging in sy dagtaak en daaglikse omstandighede, met die gevolg dat hy maklik in depressie kan versink.

\section{UITBRANDING AS BEROEPSRISIKO IN DIE BEDIENING}

Dat persone wat in bepaalde beroepe werksaam is, maklik die prooi van uitbranding kan word, is nie moeilik om te verstaan nie. Daar is sekere beroepe waarin voortdurend besonder hoë emosionele eise aan die beoefenaars daarvan gestel word. Die mediese dokter, wat verantwoordelikheid dra vir die lewe van sy pasiënte en ten spyte van sy beste pogings dikwels tevergeefs stry om 'n lewe te red, doen sy werk dikwels onder 
groot emosionele druk. Is dit egter ook waar van die predikant?

Daar is ' $n$ groot en groeiende literatuur wat handel oor die voorkoms en voorkoming van die verskynsel van uitbranding by die evangeliedienaar. In die werksituasie van die predikant is daar naamlik 'n aantal faktore aanwesig wat direk verband hou met die risiko van uitbranding. Dit is belangrik dat die predikant hierdie sake sal herken en weet hoe om daarmee om te gaan.

Sanford ${ }^{13)}$ bespreek ' $n$ aantal van hierdie sake en wys dan onder andere op die volgende:

\section{Die predikant se werk is nooit werklik klaar nie}

In baie ander beroepe beleef mense die bevrediging dat hulle ' $n$ taak kan aanpak en dit afhandel. Die predikant se werk herinner egter aan die lot van die mitologiese figuur Sisifus, wat gedoem was om altyd maar weer 'n groot klip teen 'n berg uit te rol. Elke keer wanneer hy byna die kruin bereik het, het die klip egter afgerol en moes hy maar weer van voor af begin. Die aard van die predikant se werk is so dat hy nooit werklik daarmee klaar is nie.

2. Dit is vir die predikant nie moontlik om werklik die resultate van sy werk te bepaal nie

Die ambagsman kan sien wat hy gedoen het, maar die predikant se werk is van so ' $n$ aard dat die resultate daarvan nie werklik sigbaar is nie. Wat is eintlik die kriteria vir sukses in die bediening? ' $n$ Vol kerk op Sondag? Die bedrag van die maandelikse dankoffers van die gemeente? Of dalk iets anders? Tereg skryf Hart ${ }^{14}$ ): "At the root of the 'numbers' dilemma is the fact that ministry presents problems in defining what is successful pastoring." 'n Belangrike deel van die predikant se werk is om die gemeentelike lewe in stand te hou en sorg te dra dat alles voortgaan soos dit behoort te gaan, maar juis hierin kan groot frustrasie skuil.

\section{Die werk van die predikant is herhalend van aard}

Met byna eentonige reëlmaat herhaal die pligte van die bediening hulle jaar na jaar. Huisbesoek kom nooit werklik klaar nie, elke jaar is daar weer 'n belydenisklas, week na week moet die siekes besoek word, Sondag na Sondag moet maar weer gepreek word.

4. Die bediening is 'n beroep met 'n hoë mate van sigbaarheid In die samelewing is die predikant een van die professionele persone wie 
se persoonlike lewe in sy gemeente baie bekend is. Hoewel die situasie wat dit betref in baie gemeentes gelukkig besig is om te verander, is die pastorie in 'n sekere sin nog altyd ' $n$ baie sigbare huis, waar daar minder privaatheid geniet kan word as in die meeste ander huise. Hieruit vloei dan die volgende saak.

\section{Die predikant is voortdurend daarvan bewus dat van hom verwag word om aan sekere verwagtinge te voidoen}

Of hy dit wil weet of nie, die feit bly staan dat die voortgang van sy bediening tot op groot hoogte saamhang met die wyse waarop hy deur sy gemeente aanvaar word. As hy so sou optree dat hy sy lidmate en kerkraad van hom vervreem, kan dit sy bediening in die gemeente waarin hy werksaam is, onmoontlik maak.

Baie van hierdie verwagtinge is egter vaag en onduidelik omskryf. Hv word byvoorbeeld deur sy lidmate gemeet aan die geïdealiseerde beeld wat hulle het van sy voorganger of van ' $n$ ander suksesvolle predikant met wie hulle in die verlede te doen gehad het. Bowendien is baie van hierdie verwagtinge botsend van aard en moet hy maar self besluit aan watter daarvan hy gaan probeer voidoen. Dit gee dan aanleiding tot wat Kaptein bestempel as die "habituele slegte gewete" waaraan baie predikante ly: Wanneer hulle in die gemeente op besoek is, voel hulle skuldig omdat hulle nie meer in hulle studeerkamer besig is nie, waar ' $n$ groot hoeveelheid werk lê en wag om afgehandel te word; maar wanneer hulle in die studeerkamer werk, voel hulle weer skuldig omdat hulle nie meer in die gemeente rondbeweeg nie, waar mense hulle mag nodig hê. ${ }^{15)}$

\section{Die predikant moet jaar in en jaar uit met dieselfde mense werk}

Die dokter kan weier om iemand vir wie hy nie kans sien nie as pasiënt te aanvaar, die prokureur kan dieselfde doen met 'n moeilike kliënt, maar die predikant kan nie so optree sonder om die persoon van die kerk te vervreem nie. Aan die ander kant gebeur dit ook dat persone met wie hy goed saamgewerk en aan wie hy emosioneel verbonde geraak het, uit die gemeente wegtrek. Dit kan om verskillende redes plaasvind. Sommige gemeentes is so saamgestel dat diegene wat sosiaal na 'n ietwat hoër sport in die samelewing beweeg, na beter woonbuurtes verhuis wat dikwels binne die grense van ander gemeentes geleë is. Dit is egter juis hierdie mense wat dikwels ook die leiers in die kerklike lewe is en wie se vertrek dus 'n groot leemte laat. 
7. Die feit dat 'n predikant sovee/ met mense se nood en behoeftes in aanraking kom, eis veel van hom

In sommige gemeentes word van 'n predikant 'n groot hoeveelheid krisishantering en krisispastoraat vereis, in ander weer minder, maar in elke gemeente is daar tog van tyd tot tyd krisissituasies en die predikant is maar telkens weer daarby betrokke. Die bediening is nie ' $n$ werk waarin fisies so hard gewerk word as in baie ander beroepe nie, maar omdat dit voortdurend geestelike eise aan die bedienaar stel, kan dit besonder vermoeiend wees.

8. Een van die dinge wat besonder uitputtend kan wees, is die ervaring van mis/ukking

Een van die belangrike oorsake van uitbranding is dan die ervaring van mislukte pogings: persone aan wie lank en getrou gearbei is, verlaat moontlik tog uiteindelik die kerk; dit word duidelik dat ten spyte van al sy beplanning en pogings dinge besig is om agteruit te gaan en skeef te loop op allerlei gebiede in die gemeente.

In die bediening is daar soms sprake ook van ander faktore wat tot die toestand van uitbranding kan lei. In elke besondere geval sal nagegaan moet word watter bydraende faktore 'n rol gespeel het. Sommige daarvan is die volgende:

Die persoonlikheid van die predikant: Oor die jare is reeds talle pogings aangewend om ' $n$ beeld te probeer teken van iemand wat as ' $n$ "tipiese predikant" beskryf sou kon word. Hierdie pogings was egter nie juis suksesvol nie, sodat Nauss ${ }^{16)}$ moes verklaar: "The identification of a common personality for ministers has been an elusive objective during the past 30 years of energetic clinical and psychometric effort".

'n Beeld wat deur ' $n$ bekende navorser op hierdie terrein, James $E$ Dittes, ${ }^{17}$ ' in 1971 van die persoon wat godsdiens as beroep kies, geteken is bevat trekke wat moontlik leidrade kan verskaf ten opsigte van die vraag waarom sekere predikante meer as ander uitbrandingsgeneig mag wees. Hierdie persoon sou reeds as kind beskryf kon word as 'n "little adult" of klein grootmensie. Dittes gee 'n uitvoerige beskrywing van so 'n persoon. Dit is iemand wat, vergeleke met ander kinders van sy ouderdom, meer gemaklik voel in die wêreld van die volwassenes as onder die kinders. Hy identifiseer vroeg in sy lewe reeds met die waardes van volwassenes en aanvaar al op jeugdige leeftyd verantwoordelikheid vir ander. Hy staan dus bekend as ' $n$ baie verantwoordelike kind op wie sy ouers en ander altyd kan staatmaak. Onder sy portuurgroep dwing hy 
egter meer respek af as wat hy werklik intieme vriendskapsverhoudings met sy maats aanknoop. Gevolglik kan hy 'n taamlik eensame en teruggetrokke kind wees, wat baie afhanklik is van die goedkeuring van persone in 'n gesagsposisie. Dit is die goeie kind wat vroeg reeds betrokke raak by kerklike werksaamhede en ook daarin leiding neem en later, wanneer hy 'n beroep moet kies, aangetrokke voel tot die bediening. Wanneer hy later as volwassene in die bediening staan, beleef hy dit as ' $n$ voortsetting van die patroon van sy kinderjare.

Dit kan verwag word dat so 'n persoon byvoorbeeld groot probleme sal ondervind wanneer hy by voltooiing van sy studies dienspligkapelaan word en homself onder sy portuurgroep bevind, waar hy dikwels maar min waardering vir hierdie lewensuitkyk te wagte kan wees. Daar moet natuurlik gewaak word teen veralgemening. Dit is juis die rykdom van die bediening dat daarin so ' $n$ ryke verskeidenheid van persoonlikhede en persoonlikheidstipes voorkom. Dat die beskrywing wat Dittes gee, egter wel op sommige van toepassing is, kan nie ontken word nie.

'n Volgende persoonlikheidsfaktor wat verband kan hou met uitbranding, is die sogenaamde tipe A-gedragspatroon. Hierdie gedragspatroon is in 1974 beskryf deur twee kardioloë uit San Francisco, Meyer Friedman en Ray Rosenman, in 'n boek met die titel Type A Behavior and Your Heart, waarin hulle aangetoon het dat daar ' $n$ bewysbare verband bestaan tussen die voorkoms van hartaanvalle en ' $n$ bepaalde gedragspatroon, wat deur hulle die tipe A-gedragspatroon genoem is. In 'n latere werk het Friedman die kenmerke van hierdie gedragspatroon soos volg saamgevat ${ }^{18)}$ :

1. Insecurity of status

2. Hyperaggressiveness

3. Sense of time urgency

4. Free-floating hostility, and

5. A tendency toward self-destruction.

Dit is nie hier die plek of geleentheid om breedvoerig op hierdie gedragspatroon in te gaan nie. Wat wel van belang is, is die feit dat dit verband kan hou met die verskynsel van uitbranding.

\section{FAKTORE WAT TOT UITBRANDING LEI}

Die leser wat bostaande gedeelte deurgegaan het, sou in hierdie stadium moontlik ' $n$ vraag kon stel. Al hierdie dinge is waar, maar dan is hulle tog 
waar vir alle predikante of ten minste vir 'n groot aantal. Waarom knak sommige daaronder, terwyl ander rustig jaar na jaar onder soortgelyke omstandighede voortgaan? Hoe gebeur dit dat twee persone wat in min of meer dieselfde situasie werk, so verskillend daarop sal reageer: die een gaan goed aan, maar die ander stort in duie?

Hierop het Christina Maslach lig gewerp. Sy het naamlik aangetoon dat uitbranding voorkom wanneer daar sprake is van ' $n$ samespel van veroorsakende faktore. Wanneer meer as een van hierdie faktore aanwesig is, vergroot die risiko. Drie stelle faktore speel gewoonlik 'n rol $^{19)}$ :

\section{Mense}

Die aansprake wat mense maak, kan op die lang duur oneindig veeleisend word. Elkeen se probleem is vir homself baie belangrik. Diegene wat in die sogenaamde helpende beroepe werksaam is, het egter daagliks te doen met 'n onophoudelike stroom menslike problematiek. Gewoonlik word veel van hulle verwag, maar min word teruggegee. In sekere situasies is dit natuurlik meer waar as in ander. Diegene wat dag na dag met verstandelik gestremdes of met misdadigers moet werk, ervaar dit in besondere mate. Ook in die bediening kan dit ' $n$ probleem wees. Die predikant wat maar week na week homself moet gee in sy prediking, maar nooit enige positiewe reaksie daarop kan waarneem nie; wat altyd maar moet regstaan wanneer mense sy dienste nodig het, maar steeds die gevoel het dat hy die skyf van onbillike kritiek is, loop gevaar om 'n breekpunt te bereik.

Een van die kenmerke van die sindroom van uitbranding, so is hierbo aangetoon, is dat dit lei tot 'n meer negatiewe en kritiese siening van mense. "A virtual hallmark of the burnout syndrome is a shift in the individual's view of other people - a shift from positive and caring to negative and uncaring," skryf Maslach. "People are viewed in more cynical and derogatory terms, and the caregiver may begin to develop a low opinion of their capabilities and their worth as human beings". Wanneer die liefde vir die medemens in nood verkoel en hy bloot lastig word, verdwyn die vreugde uit die omgang met mense.

\section{Werksomstandighede}

Baie mense moet onder omstandighede werk wat veeleisend en frustrerend van aard is. Nie slegs die fisiese omstandighede waaronder iemand sy werk moet verrig nie, maar veral ook diegene met wie hy moet saamwerk, speel hierin 'n rol. Vir die predikant sal dit veral sy medele- 
raar(s) en kerkraad wees. Moeilike omstandighede op hierdie gebied sal waarskynlik tot moedeloosheid en 'n gevoel van frustrasie lei, maar sal normaalweg nie tot 'n toestand van uitbranding lei nie.

Daar is egter 'n paar ander faktore wat wel 'n moeilike werksituasie onhanteerbaar kan maak. Spaniol en Caputo beklemtoon die belangrikheid van toereikende professionele voorbereiding vir die eise waarmee die persoon in die praktyk gekonfronteer gaan word. Wat hulle daaromtrent te sê het, is van soveel belang vir die bediening dat dit verdien om volledig aangehaal te word: "Professors who prepare counselors, teachers, and other helping professionals often are not themselves actively counseling, teaching, serving clients, or consulting. Because they are not practicing what they preach, their teaching becomes theoretical, cognitive, and distant. They cannot draw on experience to enliven and excite discussion. As a result, their students do not develop a strong professional identity, but rather are passive recipients of what is presented in graduate training programs. In turn, as new professionals, they carry this passive attitude into their jobs - providing knowledge is not enough. Graduate training should develop in professionals the skills they need to do their work, and the skills to teach those skills to others." 20 ) Die opleiding van akademies gevormde teoloë is nog nie ' $n$ waarborg dat hierdie persone ook in die praktyk van die bediening goed sal kan funksioneer nie. Die vorming van 'n duidelike en sterk professionele identiteit dien egter as beskerming teen die gevaar van uitbranding.

'n Verdere belangrike aspek van die werksituasie is die moontlikheid van konsultasie en begeleiding. Die werker moet iemand hê met wie hy sy probleme en frustrasies kan bespreek en van wie hy leiding kan ontvang. In baie beroepe waar met mense en hulle probleme gewerk word, is supervisie en praktykleiding gebruiklik en word dit as 'n vereiste gesien. Ervare en toegeruste persone word spesiaal hiervoor afgesonder. Tradisioneel is die bediening wat dit betref egter ' $n$ eensame beroep. Oor die moontlikheid van 'n "pastor pastorum" word soms geskryf, maar in die praktyk moet die predikant gewoonlik maar self die mas opkom. Wanneer hy werklik, probleme ondervind, is hulp nie geredelik bekombaar nie.

\section{Eienskappe van die persoon self}

Afgesien van die kenmerke waarop reeds gewys is, is daar 'n hele aantal sake wat 'n rol kan speel.

\section{${ }^{*}$ Ges/agsverskille}

Hoewel mans en vroue uitbranding op dieselfde wyse beleef, kan verwag 
word dat vroue meer bewus sal wees van emosionele uitputting en dit ook op ' $n$ meer intense wyse as mans sal beleef. Aan die ander kant is mans weer meer geneig om gedepersonaliseerd te raak en gevoelloos te word ten opsigte van diegene met wie hulle werk. ${ }^{211}$

\section{*Etniese verskille}

Maslach ${ }^{22}$ vermeld op grond van haar navorsing dat swartes nie soveel ly aan uitbranding as blankes nie. Hiervoor kan verskillende redes aangevoer word.

\section{*Ouderdom}

Dit is ' $n$ bewese feit dat jonger persone, wat oor min beroepservaring beskik maar nog vol geesdrif is en die wêreld wil versit, 'n groter risiko ten opsigte van uitbranding loop as diegene wat al oor meer ervaring beskik. Odendal ${ }^{23}$ ) verwys na navorsing wat daarop dui dat dit ook in die bediening die geval is. Predikante met ' $n$ hoë mate van uitbranding se gemiddelde jare in die bediening was 8,5 jaar, die met ' $n$ geringe mate van uitbranding se gemiddeld was 15,6 jaar. Die jonger persoon voel moontlik dat hy homself moet bewys en is ook makliker as sy ouer kollegas geneig om oorbetrokke te raak by die probleme van mense.

\section{*Huweliks- en gesinsverband}

Daar is ' $n$ konsekwente verband tussen huwelikstatus en uitbranding vasgestel: alleenlopers brand makliker uit as getroudes. (Dit het natuurlik niks te doen met Paulus se uitspraak in 1 Kor 7:9 dat dit beter is om te trou as om te brand nie!) Ook diegene wat kinders het, is minder weerloos as die kinderlose. ${ }^{24}$

\section{"Persoonlikheidseienskappe}

'n Groot aantal persoonlikheidseienskappe wat positief of negatief met uitbranding korreleer sou hier opgenoem kon word. Kortliks kom dit daarop neer dat iemand wat 'n groot behoefte aan goedkeuring het, wat gedryf word deur' $n$ sterk behoefte aan prestasie en wat probleme ondervind met beheer van sy gevoelslewe (bv iemand wat 'n lae frustrasietoleransie het en gou moedeloos word), makliker die prooi van hierdie toestand kan word. Aan die ander kant is die riglyne wat die ervare apostel Paulus aan Timoteus gegee het, ook hier van toepassing. 'n Predikant behoort woorde soos die volgende ernstig te neem: "Die Gees wat God 
ons gegee het, maak ons immers nie lafhartig nie, maar vul ons met krag, liefde en selfbeheersing" (2 Tm 1:7). "'n Dienaar van die Here moet nie rusie maak nie. Inteendeel, hy moet vriendelik wees teenoor almal, bekwaam om ander te leer en iemand wat onreg kan verdra" (2 Tm 2:24).

\section{VOORKOMING VAN UITBRANDING IN DIE BEDIENING}

Een van die tragiese gevolge van die verskynsel van uitbranding, is dat die slagoffer daarvan geneig is om homself te onttrek en enige welwillende aanbod van hulp van die hand te wys. Uit die beskrywing van die simptome van hierdie sindroom, blyk duidelik waarom. Daardeur word hy egter feitlik ontoeganklik vir hulp juis op 'n tydstip wanneer hy 'n groot behoefte daaraan het. Hy mag uit sy werk bedank en diegene met wie hy in die verlede saamgewerk het, vermy. Hy is negatief ingestel teenoor homself en ander en word ' $n$ bitter en siniese mens wat geneig is om net die negatiewe in ander raak te sien. Hy hou ook nie van homself en glo nie meer in homself nie. Daarom is dit baie belangrik om die vroeë tekens van hierdie probleem te ken en te kan herken. Dit is egter ook nodig om te weet wat gedoen kan word om dit af te weer. Voorkoming is veel beter as latere pogings tot genesing wat moontlik onsuksesvol mag wees.

Soos in baie sake, is kennis 'n magtige wapen. Hierby gaan dit nie bloot om ' $n$ teoretiese kennis van die hele aangeleentheid nie, maar veral ook oor selfkennis. Een van die dinge waaromtrent ons dikwels 'n onrealistiese beeld in ons omdra, is ons eie beperkings. Ongelukkig is die verwagtings van die kant van die gemeente dikwels ook uiters onrealisties en word van die predikant verwag om ' $n$ bedieningspatroon te handhaaf wat geen verband met die werklikheid hou nie. Die bediening kan bowendien maklik tot onegtheid aanleiding gee, omdat van die predikant verwag word om altyd positief te wees, moed in te praat, krag mee te deel en 'n goeie front voor te hou. Sy gemeente verwag nie van hom om ook by geleentheid ontmoedig te wees of te twyfel nie. Selfkennis sluit sake in soos kennis van mens se eie vrese (sommige vrees byvoorbeeld aggressiewe mense, ander het weer ' $n$ vrees vir intimiteit, terwyl dit vir nog ander groot spanning meebring om in die openbaar te moet optree), jou eie gawes, jou eie gbeie en slegte gewoontes, en dies meer.

As kennis nie lei tot 'n verstandige en gebalanseerde lewenspatroon nie, is dit nutteloos. ' $n$ Bekende predikant wat reeds jare lank in die bediening staan, vertel hoe hy as jong evangeliedienaar geglo het dat God van hom verwag dat hy homself onbeperk en tot die uiterste aan ander moes gee. Gevolglik het hy feitlik nooit gerus nie, baie ongereeld 
geëet en sy gesondheid verwaarloos. 'n Ineenstorting was onvermydelik. Gelukkig het hy betyds tot die besef gekom dat dit nie nodig was dat hy homself binne ' $n$ kort tyd moes breek en jonk moes sterwe nie, en het hy sy lewenspatroon drasties hersien. 'n Lang en geseënde bediening het gevolg.

'n Belangrike saak is om duidelike en realistiese doelwitte te stel. In die bediening is dit ' $n$ moeilike saak, maar as sonder doelwitte gewerk word, word die bediening maklik ' $n$ frustrerende gejaag om maar net te probeer bybly.

Die heel belangrikste geheim is egter om voortdurend werk te maak van vernuwing op alle lewensterreine. Uitbranding is die eindresultaat van ' $n$ proses waarin meer uitgegee word as wat ingekry word. Die voorrade moet dus voortdurend aangevul word, anders is bankrotskap onvermydelik.

Dit geld op verskillende lewensterreine: fisies, emosioneel, verstandelik en ook geestelik. Kehl25) skryf in hierdie verband: "We receive physical renewal through proper diet and rest, exercise, and wholesome recreation. Each person must work out the form of diversion that best meets his own needs: jogging, swimming, golf, tennis, handball or whatever. We receive emotional renewal through reading good books and perıodıcals, engaging in stimulating conversation, pursuing challenging interests. Most important, we receive spiritual renewal by being constantly filled with the Spirit (Eph. 5:18) and the Word of God (Col. 3:16). We must learn, as Elijah did, that nothing will offset burnout like communing with God."

'n Belangrike aspek van hierdie toerusting van die predikant is sy voortgaande teologiese studie. Hoewel dit 'n stryd is om te midde van die eise van die bediening tog nog op 'n sinvolle wyse met die teologie besig te bly, is dit die belangrikste manier waarop hy kan voorkom dat hy uitgepreek en uitgedien raak. Ray S Anderson ${ }^{26)}$ beklemtoon dat nie net die omgang met die teologie nie, maar ook die kwaliteit van die teologie wat beoefen word van belang is. "There is, I believe, a sick theology and a healthy theology which contributes to either a sick or a healthy ministry." skryf hy. "A theology which cripples and destroys the selfesteem and sense of worth of a minister is not made better by 'success' in ministry. A theology in which there is no 'sabbath rest' for the one who does the work of the ministry, is a theology of the curse, not a theology of the cross. A healthy theology contains healing for the healer and freedom for the fight of God's battles. A healthy theology, of course, is a theology of a loving God who knows that to be God is to be responsible, even for our faltering and fallible efforts." Die aankoop en bestudering van teologiese boeke en deelname aan kursusse in voortgesette teolo- 
giese opleiding is nie ' $n$ luukse vir ' $n$ predikant wat nie sy werk wil doen nie en ' $n$ uitvlug daaruit soek. Dit beteken om weer by die bronne te gaan drink.

In die besonder moet erns gemaak word met persoonlike Bybelstudie en gebed. Die predikant, wat dag na dag besig is om die Woord aan ander te bedien en vir ander te bid, kan maklik voor die versoeking swig om nie meer self tyd met die Bybel en in die gebed deur te bring nie. Wanneer die probleem van uitbranding homself begin aanmeld, lei dit bowendien tot ' $n$ gevoel van negatiwiteit en geestelike doodsheid wat nie bevorderlik is vir intieme omgang met God in die binnekamer nie. Dan is vaste gewoontes en geestelike dissipline 'n vereiste.

Die predikant wat dag na dag na die geestelike behoeftes van ander moet omsien, het ook die gebede van sy gemeentelede nodig. 'n Klein groepie kollegas, wat van tyd tot tyd op ' $n$ gereelde basis bymekaarkom vir gesprek, gebed en geestelike gemeenskap, kan ook van groot waarde wees. ${ }^{271}$

Die wetenskaplike omskrywing van die probleem van uitbranding is nog redelik nuut. Die probleem self is egter al lankal met ons, hoewel dit ongetwyfeld in toegespitste vorm in ons tyd voorkom. 'n Klassieke beskrywing daarvan vind ons in die geskiedenis van die profeet Elia in 1 Konings 19.

Kehl toon aan hoe ons by Elia sekere tipiese trekke terugvind van die verskynsel van uitbranding, soos ons dit in ons dag ken. Die insinking het byvoorbeeld gekom net na 'n hoogtepunt, waar besondere eise aan die geesteskrag van die profeet gestel is. Net na sy triomf trek hy die woestyn in, waar hy uiteindelik ook sy dienskneg agterlaat. Hy onttrek hom aan mense en gaan sit in die skraal skaduweetjie van die besembos, oorweldig deur depressie en wanhoop. Hy is heeltemal uitgeput: liggaamlik, psigies, emosioneel en geestelik. Sy enigste reaksie is: "Dit is genoeg, Here! Neem my lewe, want ek is niks beter as my voorvaders nie." Hy voel nie net eensaam en verlate nie, maar ook verbitterd teenoor mense, wanneer hy kla: "Ek het my met hart en siel gewy aan u saak, Here, Almagtige God ... Net ek alleen het oorgebly, en hulle soek my om my ook om die lewe te bring." Dit is duidelik dat hy nie meer duidelik kan onderskei nie en veralgemeen: Nie meer Isebel nie, maar "hulle" is op sy spoor.

Die weg tot genesing word egter ook duidelik geteken: Rus, voedsel, 'n nuwe ontmoeting met God, wat nie verwyt nie, maar verstaan en vernuwe. Daarom kon Elia uit die woestyn kom met ' $n$ nuwe opdrag en met nuwe krag om dit uit te voer. Dit is geen wonder dat hierdie geskiedenis een van die bekendste en mees geliefde in die Ou Testament is nie. Dit spreek ons aan oor 'n probleem wat ons maar alte goed ken! 


\section{NOTAS}

1. D A Hart, "Pastor burnout: an introduction", Theology, News and Notes 31/1(1984), 2.

2. J A Sanford, Ministry burnout, London 1982, 2.

3. Die predikant en uitbranding, Johannesburg 1984, 1.

4. D A Taylor, Burnout among Southern Baptist and United Methodist ministers and professional religious workers in Dallas and Tarrant counties, Texas 1982, 28.

5. L A Gouws, D A Louw, W F Meyer, C Plug, Psigologie-woordeboek, Johannesburg 1979, 276.

6. Cf B Perlman, E A Hartman, "Burnout: Summary and future", Human Relations 35/4 (1982), 283-305.

7. C Maslach, Burnout - the cost of caring, Englewood Cliffs 1982.

8. Maslach, aw, 2.

9. Maslach, aw, 10.

10. Soos aangehaal deur Taylor, aw, 16.

11. A D Hart, "Understanding burnout", Theology, News and Notes 31/1 (1984), 5-6.

12. A D Hart, Coping with depression in the ministry and other helping professions, Waco, Texas 1984, 114.

13. Sanford, Ministry burnout, 1982.

14. Hart, Cooing with depression, 118.

15. R Kaptein, De predikant: Zijn plaats en taak in een nieuwe wereld, Amsterdam 1966, 115.

16. A Nauss, "The ministerial personality: Myth or reality?", Journal of Religion and Health 12 (1973), 77.

17. J E Dittes, Psychological characteristics of religious development: A comprehensive handbook, New York 1971, 429-434.

18. Soos aangehaal deur $L$ Yoder, "Modifying the type A behaviour pattern", Journal of Religion and Health 26/1 (1987), 58.

19. Maslach, aw, 17.

20. Le R Spaniol, J Caputo, "How to recognize, cope with and avoid professional burnout", Instructional Innovator 25 (1980), 19.

21. Maslach, aw, 58.

22. Maslach, aw, 59 .

23. Odendal, aw, 39.

24. Maslach, aw, 61.

25. D G Kehl, "Burnout: The risk of reaching too high", Christianity Today 20 (1981), 1577.

26. R S Anderson, "Burnout as a symptom of theological anemia", Theology, News and Notes 31/1 (1984), 13.

27. Vgl G R Collius, "The hazard of professional people-helpers", Christianity Today 21 (1976), 740-742. 